Kansas makes a monkey of itself

Sir — When the journalist H. L. Mencken reported on the infamous Scopes trial of 1925 , he remarked that the hysteria surrounding it had made a "universal joke" out of the occupants of Dayton, Tennessee, where the trial took place. Now, 74 years later, but only a few degrees of longitude removed, the Kansas Board of Education has in its turn made a monkey of itself. The board has removed the requirement for school students to have a knowledge of evolution to pass examinations (Nature 400, 697 \& 701; 1999).

This might seem hilarious in today's technically wired society were it not for one sobering fact. Despite overwhelming acceptance of the material benefits that science has brought, Americans in general remain deeply ignorant of its basic principles. If such ignorance persists, it will prove devastating to the future of our democracy whose citizens will increasingly be called upon to exercise judgement on the complex social issues that advances in science inevitably bring.

As an illustration in the context of the Kansas decision, consider this - one of the most profound legacies of twentieth-century science for the next millennium is the discovery of the molecular structure of DNA in the 1950s. That provided the physical basis to begin to understand the processes of evolution on a genetic and cellular scale. In a few more decades, we will probably gain the knowledge to effect and accelerate, through directed genetic modification, the evolution of all life forms - including ourselves.

How we use this power, arguably the most potent ever to be possessed by humankind, will present the greatest social challenge to the survival of our species since the first primates stood up in the bushes, or, as they might now say in Kansas, since Adam awoke in Eden. We will have taken a big bite out of the apple of the Tree of Knowledge, surpassing even that which released the secrets within the atomic nucleus. Whether we use the former to create the horror of a Huxleyan Brave New World or to enhance our basic humanity will be strictly up to us, just as is the decision on whether to use the latter for peaceful purposes or to bring about nuclear holocaust.

Thomas Jefferson, perhaps the prime champion among the founding fathers of the principle of separation of church and state, envisioned an American republic governed by a wise and educated electorate. To place at risk for the children of Kansas the chance to obtain all the vital knowledge that will enable them to keep Jefferson's dream alive in the coming age of biological revolution is both deplorable and terrifying. Paul M. Grant

EPRI, 3412 Hillview Avenue, Palo Alto,

California 94304-1395, USA

\section{Global emissions could soon start rising again}

Sir-Some loose ends appear in your report of the Worldwatch Institute's estimates of global carbon emissions from fossil fuel use in 1998 (Nature 400, 494; 1999). The industry report cited estimated that global emissions had fallen by $0.47 \%$ from 1997 levels, based on a US reduction of $0.2 \%$. The US Environmental Protection Agency later estimated that 1998 US emissions had increased by $0.4 \%$. This indicates that global emissions declined by $0.3 \%$. The Worldwatch Institute claimed a $0.5 \%$ global reduction, despite acknowledging the $+0.4 \%$ US figure.

In fact, the global reduction seems to have been more than $1 \%$. This is owing to a reduction of more than $3 \%$ in the Asia-Pacific region and of more than $2 \%$ in the economies in transition in Eastern Europe and the former Soviet Union. Developing countries overall saw a decline exceeding 3\% (though still up 33\% on 1990 levels) because the decline in Asia more than offset small increases elsewhere. By contrast, emissions rose $1 \%$ in the European Union.

Reductions around the world were mainly the result of presumably temporary economic difficulties. In many cases they occurred in countries that are neither industrialized nor transitional economies listed in annex I of the climate convention and annex B of the Kyoto Protocol.

The Worldwatch Institute's belief that the 1998 figures are "a sign that it may be less difficult to slow global warming under the Kyoto Protocol" than has been widely assumed, and the suggestion by others that voluntary reductions by industry will suffice, seem seriously complacent. Michael Jefferson The Old Stables, Felmersham, Beds MK43 7HJ, UK

\section{Alois Alzheimer and the amyloid debate}

Sir - Peter St George-Hyslop and David Westaway discuss the possibility of using $\mathrm{A} \beta$ immunization to treat Alzheimer's disease ${ }^{1}$. They mention the continuing controversy ${ }^{2,3}$ surrounding the role of extracellular $A \beta$ accumulation and amyloid plaques in the causation of the dementia associated with the disease, referring to this as "an old debate". What is not widely recognized is how old the question at the centre of this debate actually is.

Alois Alzheimer and his contemporaries ${ }^{4}$ considered this very question. In a 1911 paper entitled "On certain peculiar diseases of old age", Alzheimer writes: "There are cases of indubitable Dementia senilis, in which the plaques are not very numerous. Moreover, as Fischer stresses, they dislocate the nervous structures more than they destroy them. So the loss of cortical tissue due to the plaques cannot be very considerable. Furthermore, in places where plaques are not found in the cerebral cortex, we see the well-known widespread senile sclerotic changes, the lipid-pigmented and granular degenerations of ganglion cells with alterations of their fibrils which Brodmann and Bielschowsky have described in detail, the fibre-formation of the glia, pigmentaccumulation in the glia and the degenerative phenomena in the vessel-walls which it is impossible to believe were caused by plaques.

"These changes are found in the basal ganglia, the medulla, the cerebellum and the spinal cord, although there are no plaques at all in those sites or only isolated ones. So we have to conclude that the plaques are not the cause of senile dementia but only an accompanying feature of senile involution of the central nervous system."

The italics are Alzheimer's and the translation is by Hans Förstl and Raymond Levy ${ }^{6}$. The paper was written by Alzheimer after his examination of only three patients with the disease. It is a remarkable testament to his meticulous work and originality of thought that 88 years ago he put forward an analysis that is not out of place in the context of the current debate. John N. Davis II ${ }^{\star}$ J Jane C. Chisholm $\dagger$ ${ }^{*}$ Department of Neurology, University of Virginia, Charlottesville, Virginia 22908, USA $\dagger$ Department of Pharmacology and Physiology, University of Rochester,

Rochester, New York 14642, USA

1. St George-Hyslop, P. \& Westaway, D. Nature 400, 116-117 (1999).

2. Hardy, J. H. Trends Neurosci. 20, 154-159 (1997).

3. Davis, J. N. \& Chisholm, J. C. Trends Neurosci. 20,558-559 (1997).

4. Bick, K. et al. (eds) The Early Story of Alzheimer's Disease

(Liviana, New York, 1987).

5. Alzheimer, A. Zschr ges Neurol. Psychiat. 4, 356-385 (1911).

6. Förstl, H. \& Levy, R. History of Psychiatry 2, 71-101 (1991). 